依頼論 文 《誌上ディベイト＼cjkstart鋳造コアかレジンコアか》

適切な支台築造法を求めて

福島 俊士

\title{
Clinical Consideration of Foundation Restoration for Endodontically Treated Teeth
}

Fukushima Shunji

\begin{abstract}
抄 録
鋳造コアとレジンコアとを比較するとき，レジンコアにレジン単体のものと既製ポストを併用したレジ ンコアとがあることに注意が必要である．また，レジンコアの材料として，歯質とくに象牙質に接着す る材料を使用できるようになったことも重要である．適切な支台築造法ということで，今日もっとも考 えなければならないのは，眼前の窩洞に対する金属ポストの必要性である．この意味では，鋳造による ものか既製金属のものかを問わない．歯冠部に歯質が十分残っているならば，いずれの金属ポストも使 うべきでない，金属ポストと歯質との間に物性の差に由来する応力が発生するからである，このメッ セージを的確に伝えているのがレジン単体の築造法である.このような観点から，鋳造コアとレジンコ アの使い分けが必要かとの設問 1 には，レジン単体が適応の症例では大いに必要であると答えた. ま た，それぞれの築造法に適した症例をあげよとの設問 2 には，特に既製ポスト併用レジン築造法につい て, その利点を製作に要する時間および経費の節減など, 主に臨床的立場からのメリットを述べた。さ らに, 支台築造に起因するトラブルの防止策を問う設問 3 には, 歯に作用する力を調整する加圧要素の コントロールと, それを受ける歯の対応策として, 受圧要素のコントロールの重要性を具体的に指摘し た.
\end{abstract}

和文キーワード

鋳造コア, レジンコア, 既製ポスト, 支台築造 


\section{I. はじめに}

日常臨床において，失活歯に支台築造する機会は多 く，また，支台築造に起因するトラブルに遭遇するこ とも比較的多い. 支台築造を的確に行うために，現在 広く行われている鋳造コアとレジンコアについて，両 者の得失を点検することが本企画の趣旨と思われる.

本稿では，われわれが取り組んできた支台築造に関 する知見に基づいて，与えられた設問にできるかぎり 正面から答えてみたい.

\section{II. 設問 1 鋳造コアとレジンコアの使い分けは 必要か}

レジンコアには大別して 2 種類ある.1つはレジン
だけのもの（以下，レジン単体)，もう1つは既製金 属ポストとレジンコアを組み合わせたもの（以下，既 製ポスト併用レジン築造) である。

鋳造コアとレジン単体のものの使い分けは，ぜひ必 要である．前者は支台築造する歯の歯冠部歯質がほと んど残っていない症例が適応症であり，後者は歯冠部 歯質がかなり残っている症例が適応症である。

それでは，どの程度残っていればレジン単体でいい のだろうか？それを調べるためにわれわれは実験 1)を行った。すなわち，ヒトの単根歯を用い，歯冠 部の残存歯質量が $0,1,2,4 \mathrm{~mm}, 4 \mathrm{~mm} \times 1 / 2$ の条 件を付与し（図 1), レジン単体, 既製ポスト併用レ ジン築造, 鋳造コアの 3 種類の方法で支台築造し（図 2)，これらに静的な荷重を加え，破折に要する強度， すなわち破折強度を測定した。その際，支台築造した うえにクラウンを装着したもの（以下，クラウンあ

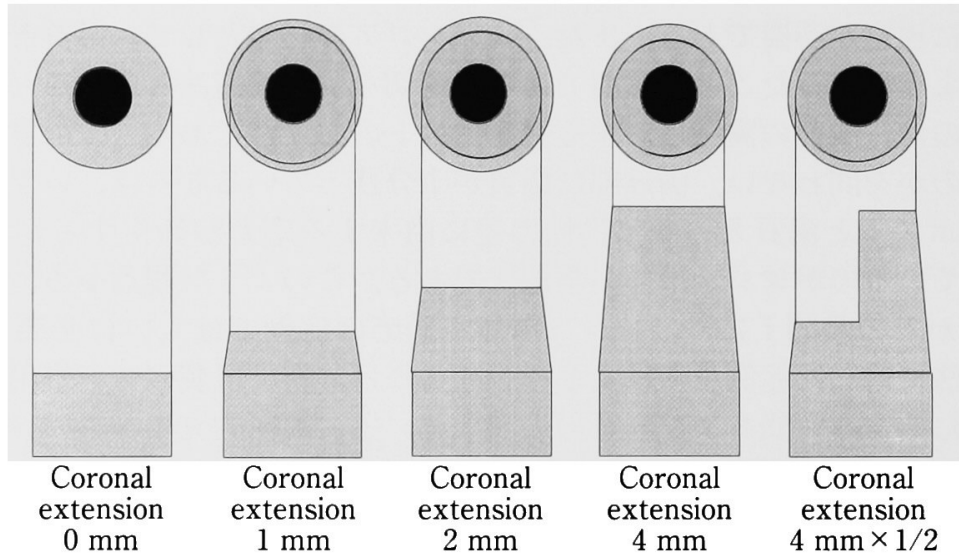

図 1 Tooth preparation designs 築造窩洞形態

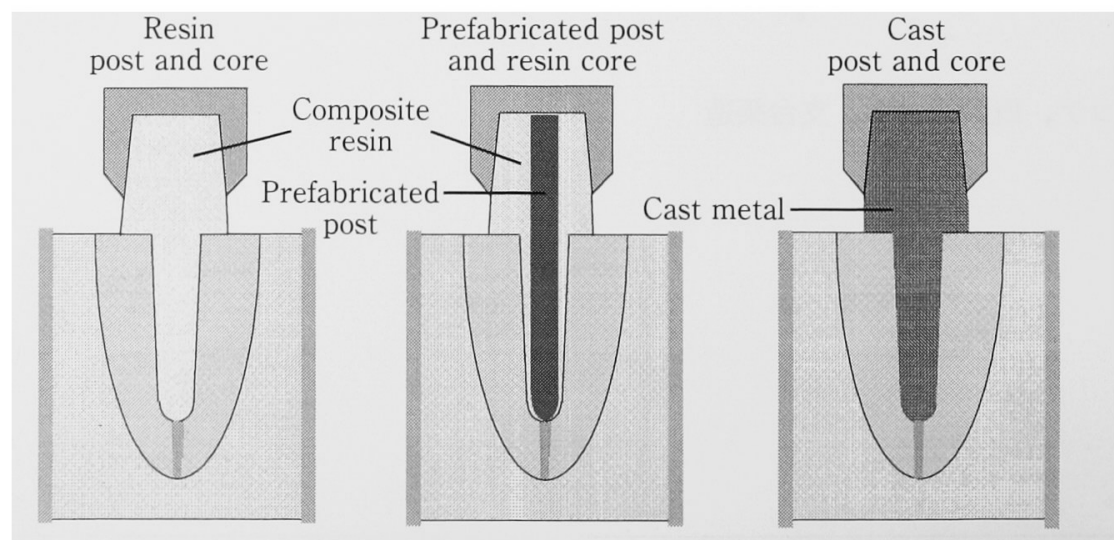

図 2 Post and core designs 築造方法別の模式図 


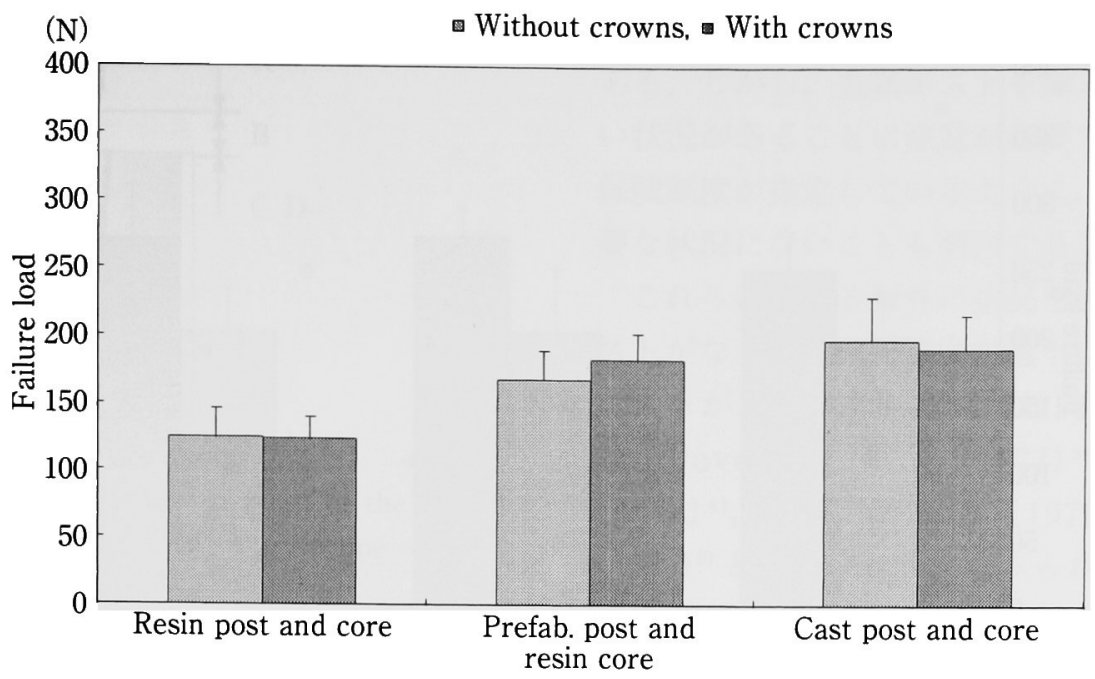

図 3 Failure loads at $0 \mathrm{~mm}$ coronal extension 歯冠部残存歯質量 $0 \mathrm{~mm}$ のときの破折強度

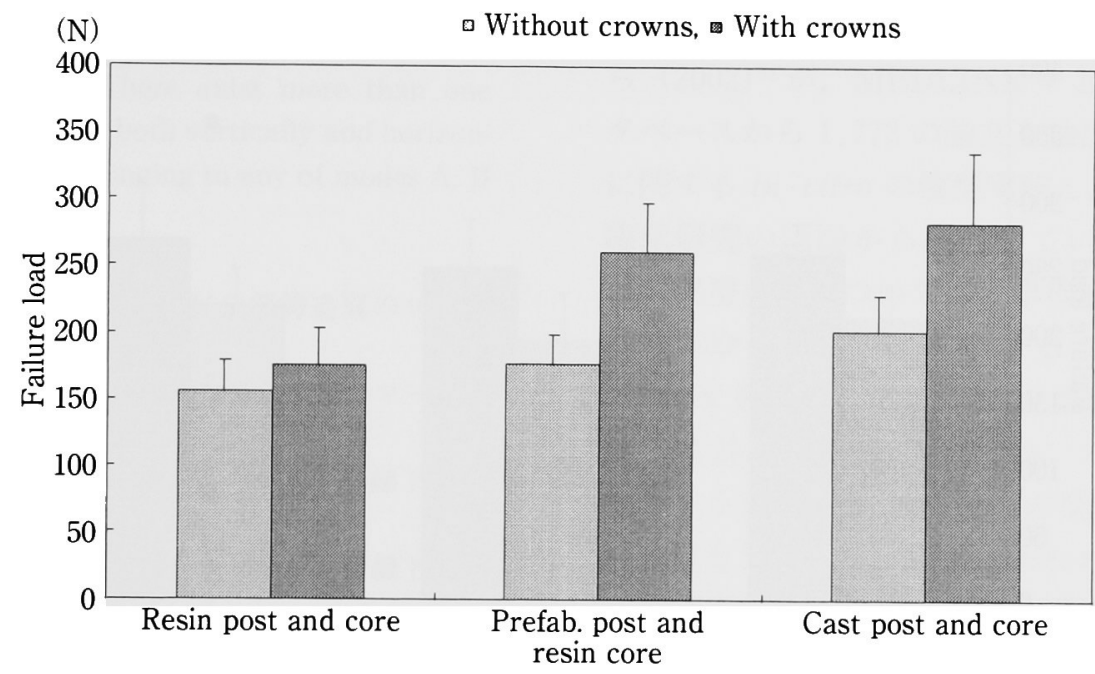

図 4 Failure loads at $1 \mathrm{~mm}$ coronal extension 歯冠部残存歯質量 $1 \mathrm{~mm}$ のときの破折強度

り）と, 装着しないもの（以下，クラウンなし）の両 方について実験した。ここで強調すべきは，コア材料 として象牙質に対して優れた接着力を示すコア用のコ ンポジットレジン2)を使ったことである.

図3〜6 はその結果で, 図 3 は残存歯質量 $0 \mathrm{~mm}$ の 場合である. 3 種類の築造法を比べると, レジン単体 のものはほかの方法と比べ破折強度が有意に低かっ た.すなわち, 残存歯質量が $0 \mathrm{~mm}$ のときは, レジン 単体での築造法は無理ということである. 図 4 は 1 $\mathrm{mm}$ のときで, クラウンなしのときは, 鋳造コアがレ ジン単体よりも破折強度が有意に高かった。また，ク
ラウンありのときは，鋳造コアと既製ポスト併用レジ ン築造が，レジン単体よりも有意に高かった。すなわ ち, 残存歯質量が $1 \mathrm{~mm}$ ではレジン単体での築造は望 ましくないことになる.

ところが図 5 の $2 \mathrm{~mm}$ のときには, クラウンありの ときも，なしのときも築造法による差がなくなってい た. 図 6 の $4 \mathrm{~mm}$ のときも所見は同様であった。

このように破折強度の観点から, 鋳造コアとレジン 単体との使い分けが必要であるが, 実は別の観点, す なわち，破折した歯を再利用できるか否かの視点か ら, もう一度 3 種類の築造法を点検すると, さらに興 


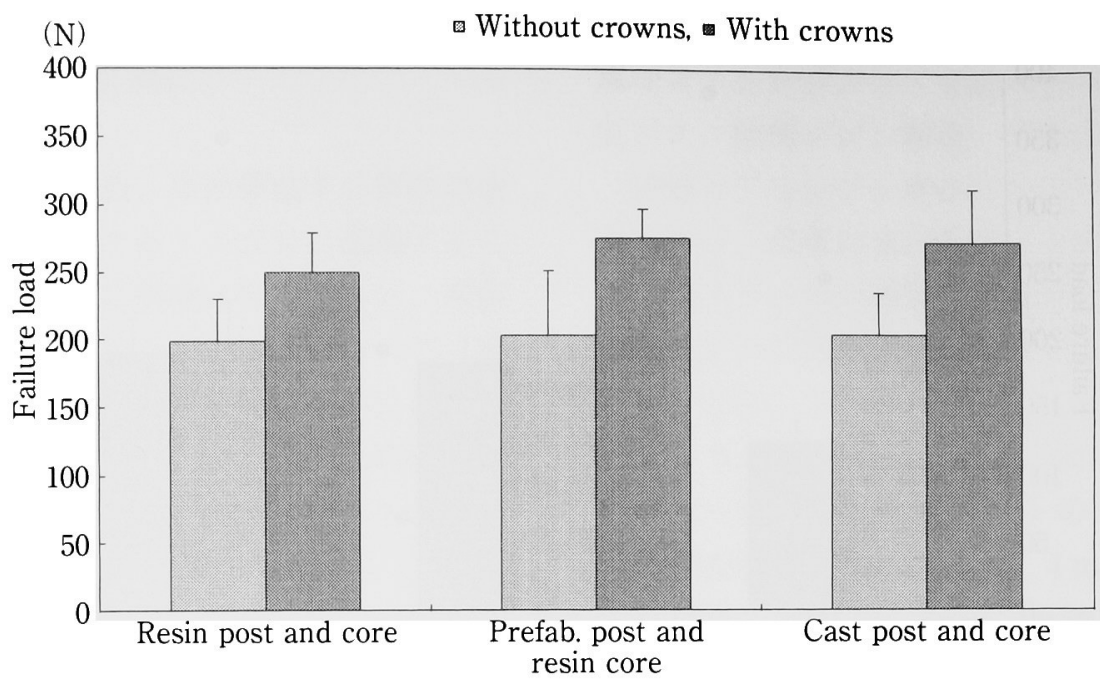

図 5 Failure loads at $2 \mathrm{~mm}$ coronal extension 歯冠部残存歯質量 $2 \mathrm{~mm}$ のときの破折強度

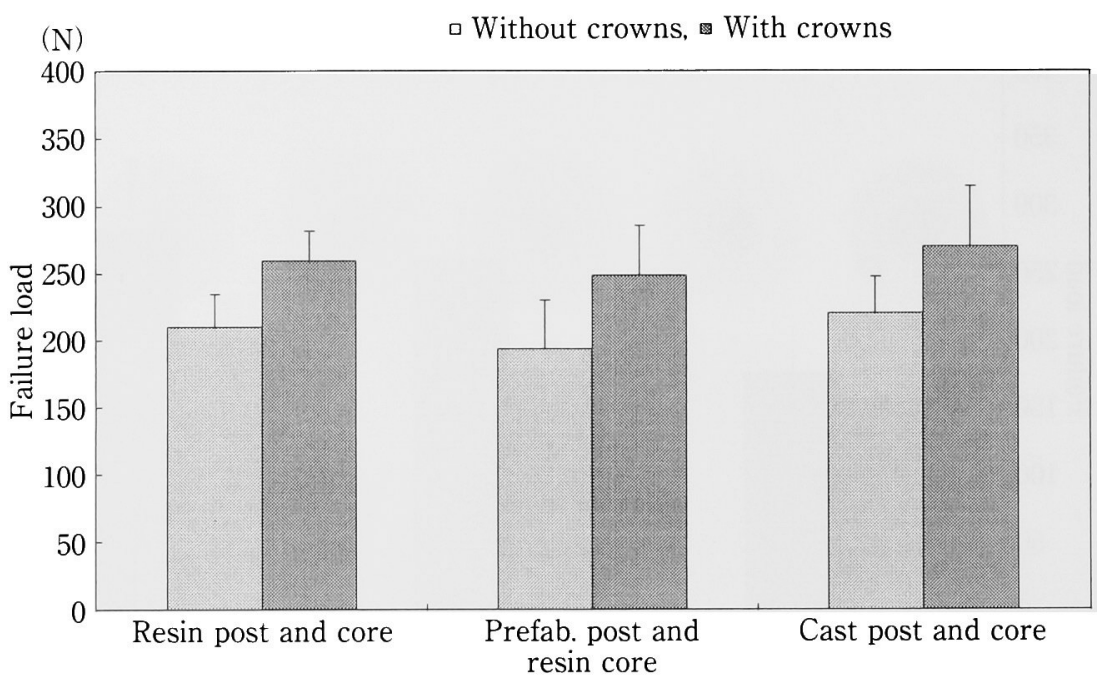

図 6 Failure loads at $4 \mathrm{~mm}$ coronal extension 歯冠部残存歯質量 $4 \mathrm{~mm}$ のときの破折強度

味深い. その際，再利用の可否は破折様相によって分 類することにし，破折線がクラウン内に留まったか， 歯槽骨縁下（実験ではレジンブロック内）にまで達し たかによって判断した（図 7)。すなわち，歯槽骨縁 下に達した図中の C，D の場合には，再利用困難と判 断することになる。その結果は表 1 に示す通りで, 最 下段の鋳造コアは残存歯質量が $0,1,2 \mathrm{~mm}$ のとき, 10 本の試料中 6,7 本は歯槽骨縁下に達していた。こ れに対し，レジン単体はすべての残存歯質の条件にお いて歯槽骨縁下に達することがなかった。すなわち， 残存歯質が $2 \mathrm{~mm}$ 以上あるならば，ぜひレジン単体の
築造をすべきことになる.

一方，鋳造コアと既製ポスト併用レジン築造の使い 分けについては，上記の通り破折強度，破折様相いず れの観点からもほとんど差がない.ただし，製作の容 易さや審美性などに関しては差があるので，これらに ついては次の設問への回答で点検することにする.

破折強度，破折樣相に関する以上の所見は，シミュ レーション実験から得られたものであって，実際のロ 腔内からのものではない. 特に歯根膜の有無が大きく 影響するかもしれない（実験 1 では歯根膜に相当する 層はない).したがって， $2 \mathrm{~mm}$ という絶対值にどれ 


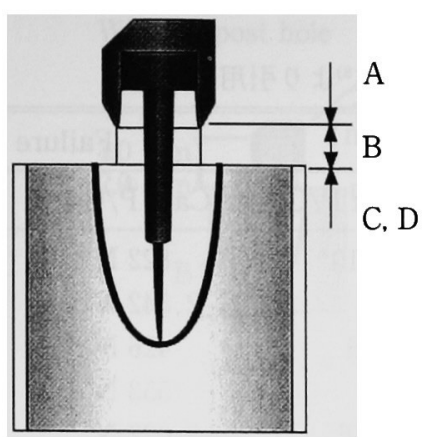

図 7 Classification of fracture modes

Fracture mode A : The lowest point of the fracture line is located above the margin line of the full cast crown

Fracture mode B: The lowest point of the fracture line is located between the margin and the tooth root embedded in the resin

Fracture mode $\mathrm{C}$ : The lowest point of the fracture line is reaching the inside of the tooth root embedded in the resin

Fracture mode D: There exist more than one fracture line that run both vertically and horizontally (Others not belonging to any of modes A, B and C)

破折様相の分類

破折様相 A：破折線の下緑が全部鋳造冠のマージ ンより上部にある

破折様相 B：破折線の下縁が全部鋳造冠のマージン から包埋レジンの間にある

破折様相 C：破折線の下縁が包埋レジンの緑下に及 んでいる

破折様相 D：破折線の下縁が包埋レジンの縁下で, 横破折と縦破折が混在している
ほどの意味があるかに関しては臨床的な検討が必要で ある。しかし，金属ポストを挿入しないほうが望まし い状況があることに注意が必要である．また，現行の 保険制度が指定しているように，既製ポストが必ず必 要な状況にないことも明白である。

これらに関する海外の状況を通覧すると，金属のポ ストがなくても破折強度が低下しない，あるいは金属 ポストがあっても破折強度は向上しないという論文 は, Lovdahl PEら (1977) ${ }^{3)}$, Trabert KC ら $(1978)^{4)}$, Guzy GE ら (1979) ${ }^{5)}$, Trope M ら $(1985)^{6)}$ と，随分以前からみられる。また，臨床的な 疫学研究として, 鋳造ポストがあってもなくても支台 築造の失敗率に差がなかったとする Sorensen JA ら $(1984)^{7)}$ の論文がある。

また，鋳造コアと既製ポスト併用レジン築造（ただ し直接法）との比較に関しては, 最近 Heydecke G ら $(2002)^{8)}$ が，MEDLINEゃ EMBASE などのデー タベースから 1,773 の論文を抽出し, 破折強度と様相 に関する in vitro の模型実験と, in vivo の疫学的な 臨床研究の両面から検討している。その結果によれ ば，模型実験については，単根歯であることや荷重方 向が 130〜135の範囲にあることなどの Inclusion criteria を適用したところ 10 論文 ${ }^{9 \sim 18)}$ が残り，破折強 度（表 2)，破折様相いずれについても鋳造コアと既 製ポスト併用レジン築造との間に有意差はみられな かったとしていて，前記のわれわれの結果とよく一致 している.また, 臨床研究に関しては, 前歯のデー夕 があること， 3 年以上の経過があることなどの Inclu-

表 1 Fracture modes of the specimen types with crowns 築造方法別の破折様相（クラウンあり）

\begin{tabular}{|c|c|c|c|c|c|c|c|}
\hline Post and core types & $\begin{array}{l}\text { Fracture } \\
\text { modes }\end{array}$ & $0 \mathrm{~mm}$ & $1 \mathrm{~mm}$ & $2 \mathrm{~mm}$ & $4 \mathrm{~mm}$ & $\begin{array}{c}4 \mathrm{~mm} \times 1 / 2 \\
\left(\begin{array}{l}\text { Loaded to } \\
\text { core side }\end{array}\right)\end{array}$ & $\begin{array}{c}4 \mathrm{~mm} \times 1 / 2 \\
\left(\begin{array}{l}\text { Loaded to } \\
\text { tooth side }\end{array}\right)\end{array}$ \\
\hline \multirow{3}{*}{ Resin post and core } & A & 10 & 10 & 0 & 0 & 7 & 2 \\
\hline & $\mathrm{B}$ & 0 & 0 & 10 & 10 & 3 & 8 \\
\hline & C, D & 0 & 0 & 0 & 0 & 0 & 0 \\
\hline \multirow{3}{*}{$\begin{array}{l}\text { Prefabricated post } \\
\text { and resin core }\end{array}$} & $\mathrm{A}$ & 0 & 0 & 0 & 0 & 0 & 0 \\
\hline & $\mathrm{B}$ & 3 & 2 & 4 & 3 & 2 & 4 \\
\hline & C, D & 7 & 8 & 6 & 7 & 8 & 6 \\
\hline \multirow{3}{*}{ Cast post and core } & A & 0 & 0 & 0 & 0 & 0 & 0 \\
\hline & $\mathrm{B}$ & 3 & 4 & 3 & 5 & 2 & 6 \\
\hline & C, D & 7 & 6 & 7 & 5 & 8 & 4 \\
\hline
\end{tabular}


表 2 Failure loads in 10 selected studies

選別された 10 論文の破折強度（Heydecke G ら論文 ${ }^{8)}$ より引用）

\begin{tabular}{|c|c|c|c|c|c|c|}
\hline \multirow{2}{*}{ Study } & \multirow{2}{*}{$\begin{array}{l}\text { Selected for } \\
\text { meta-analysis }\end{array}$} & \multirow{2}{*}{ Testing procedure } & \multicolumn{2}{|c|}{ Sample size } & \multicolumn{2}{|c|}{ Failure level } \\
\hline & & & Cast $\mathrm{P} / \mathrm{C}$ & Direct $\mathrm{P} / \mathrm{C}$ & Cast $\mathrm{P} / \mathrm{C}$ & Direct $\mathrm{P} / \mathrm{C}$ \\
\hline Akkayan and Caniklioglu ${ }^{9)}$ & Yes & Static loading & 10 & $10 / 10^{*}$ & $822 \mathrm{~N}$ & $1,053 \mathrm{~N}$ \\
\hline Assif et $\mathrm{al}^{10)}$ & & Static loading & 10 & & $2,542 \mathrm{~N}$ & \\
\hline Butz et $\mathrm{al}^{11)}$ & Yes & Cyclic and static loading & 16 & 16 & $426 \mathrm{~N}$ & $425 \mathrm{~N}$ \\
\hline Kern et $\mathrm{al}^{12)}$ & Yes & Static loading & 10 & & $553 \mathrm{~N}$ & \\
\hline Martinez-Insua et $\mathrm{al}^{13 \text { ) }}$ & & Static loading & 22 & $22^{\dagger}$ & $2,027 \mathrm{~N}$ & $1,037 \mathrm{~N}$ \\
\hline Perez Moll et $\mathrm{al}^{14)}$ & & Static loading & 30 & & $419 \mathrm{~N}^{\#}$ & \\
\hline Sidoli et $\mathrm{al}^{15)}$ & & Static loading & 10 & 10 & $15.3 \mathrm{MNm}^{-2}$ & $14.2 \mathrm{MNm}^{-2}$ \\
\hline Robbins et $\mathrm{al}^{16)}$ & Yes & Static loading & & $10 / 10^{*}$ & & $530 \mathrm{~N}$ \\
\hline Isidor and Brondum ${ }^{17)}$ & & Cyclic loading & 12 & 12 & 22,700 cycles & 95,000 cycles \\
\hline Isidor et $\mathrm{al}^{18)}$ & & Cyclic loading & & 14 & & $>260,000$ cycles \\
\hline
\end{tabular}

$\mathrm{P} / \mathrm{C}$ : Post and core, ${ }^{*}$ Equal numbers of specimens with tapered and parallel posts were reported, ${ }^{\dagger}$ Carbon-fiber posts (excluded from meta-analysis), "No standard deviations reported

表 3 Success rate (\%) of post and cores in 6 selected clinical studies 選別された 6 論文における支台築造の成功率 (Heydecke G ら論文 ${ }^{8)}$ より引用)

\begin{tabular}{|c|c|c|c|c|c|c|c|}
\hline \multirow{2}{*}{ Study } & \multirow{2}{*}{$\begin{array}{l}\text { Follow-up } \\
\quad \text { (years) }\end{array}$} & \multirow{2}{*}{$\begin{array}{c}\text { Total } \\
\text { sample }\end{array}$} & \multicolumn{2}{|c|}{ Sample size } & \multicolumn{2}{|c|}{ Success $(\%)$} & \multirow{2}{*}{ Comment } \\
\hline & & & Cast $\mathrm{P} / \mathrm{C}$ & Direct $\mathrm{P} / \mathrm{C}$ & Cast $\mathrm{P} / \mathrm{C}$ & Direct $\mathrm{P} / \mathrm{C}$ & \\
\hline Bergman et al $^{19)}$ & 6 & 96 & 39 custom & & 87.2 & & Survival detectable \\
\hline Hatzikyriakos et $\mathrm{al}^{20)}$ & 3 & 187 & 33 & $41 \mathrm{~S}, 28 \mathrm{PP}$ & 93.0 & $90.3 \mathrm{~S}, 89.3 \mathrm{PP}$ & Success calculated \\
\hline Linde et $\mathrm{al}^{21)}$ & 9.5 & 59 & 0 & $27 \mathrm{~S}$ & & 67.9 & Compromised teeth \\
\hline Mentink et $\mathrm{al}^{22)}$ & 8 & 112 & 0 & $25 \mathrm{~S}$ & & 92.0 & 3 different types of screws \\
\hline Mentink et $\mathrm{al}^{23)}$ & 4.8 & 516 & 206 Permador & 0 & 88.9 & & Survival detectable \\
\hline Torbjörner et $\mathrm{al}^{24)}$ & $4-5$ & 788 & 422 & 0 & 92.5 & & Success calculated \\
\hline
\end{tabular}

$\mathrm{P} / \mathrm{C}:$ Post and core, $\mathrm{S}:$ Screw, PP : ParaPost

sion criteria を設けたところ 6 論文 ${ }^{19 \sim 24)}$ が残ったもの の, 無作為化臨床試験（Randomized clinical trials）に該当する研究は 1 論文もなく, 生存率の比 較は困難であったとしている（表 3)。

\section{III. 設問 2 鋳造コアがレジンコアよりも適 していると考えられるのはどんな場合 か．逆にレジンコアが鋳造コアよりも適 していると考えられるのはどんな場合か}

前記の内容に沿って回答すると，歯冠部の残存歯質 量が多い場合には，レジン単体としてのレジンコアが 鋳造コアよりも適している。破折強度は同様で破折様 相が優れているからである。これはレジンコアの機械 的性状が象牙質に近く，応力が局所に集中しにくいた めと理解できる。
これに対し，残存歯質量が少ない場合には，レジン 単体は鋳造コアよりも破折強度が著しく劣り, 鋳造コ アが適している．ただし，既製ポスト併用レジン築造 としてのレジンコアは, 鋳造コアと同等と評価でき る.これに関しては，ポストの引き抜き強さ25,26)や色

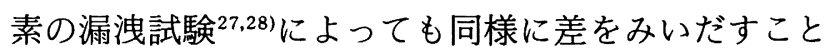
ができていない.

そこで，この両者の比較を別の視点すなわち臨床的 に比較すると, 既製ポスト併用レジン築造が鋳造コア よりも優れている点として次の事項をあげることがで きる．すなわち，1．製作に要する時間や経費を節約 できる, 2. 健全歯質を保存できる可能性が高い, 3 . 上部構造としてオールセラミッククラウンを装着する 場合に，金属色がないため審美性に優れる，4.レジ ンコアは直接法で製作することができるので，その日 のうちに支台歯形成できる，などである. 


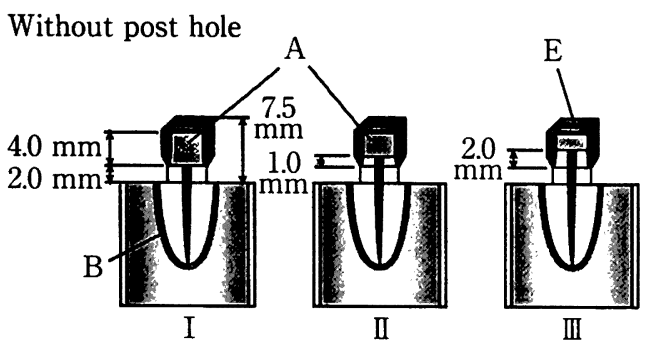

A : Composite resin (Clearfil DC core)

B : Artificial periodontal membrane

(Silicone impression material)

C : Prefabricated post

(AD Post II )

$\mathrm{D}$ : Luting cement

(Panavia Fluoro Cement)

E : Cast metal

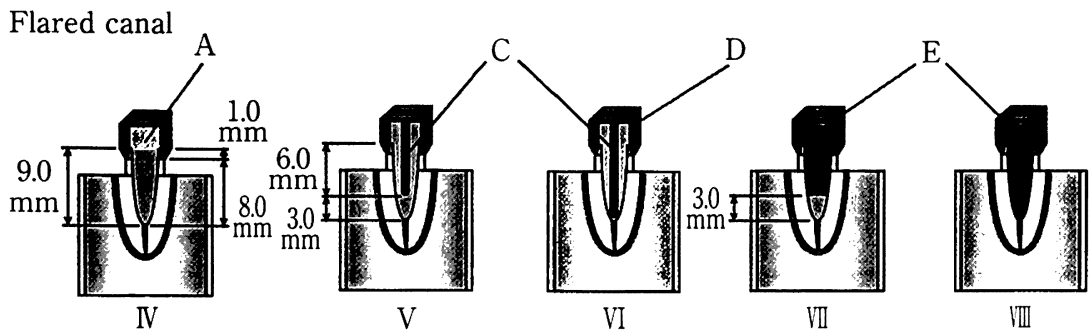

図 8 Schematic description of the specimen types

I : Composite resin core without post hole

(Height of the remaining crown of the natural tooth is $0 \mathrm{~mm}$ )

II : Composite resin core without post hole

(Height of the remaining crown of the natural tooth is $1 \mathrm{~mm}$ )

III : Composite resin core without post hole

(Height of the remaining crown of the natural tooth is $2 \mathrm{~mm}$ )

IV : Composite resin post and core

$\mathrm{V}$ : Prefabricated post and composite resin core

(The post hole is $3 \mathrm{~mm}$ longer than the post)

VI : Prefabricated post and composite resin core

VII : Metal post and core

(The post hole is $3 \mathrm{~mm}$ longer than the post)

VIII : Metal post and core

築造方法別の模式図

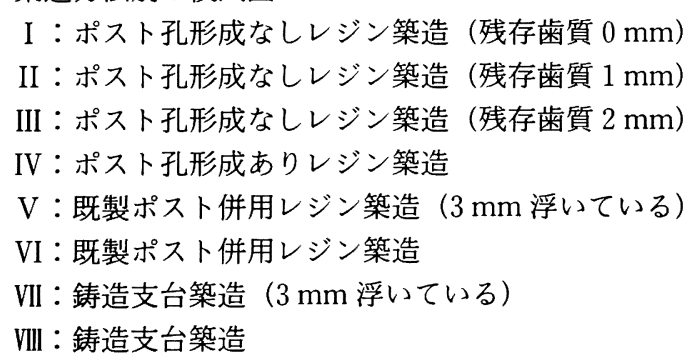

一方，われわれは歯根部の残存歯質が少ない, いわ ゆる漏斗状根管に対して，どの方法による築造法が優 れているか，新たに実験 $2^{29)}$ 行った。すなわち， 3 段階の残存歯質量にレジン築造したものと，漏斗状根 管に 5 種類の方法で築造したものとを比較検討した (図 8)。その結果を初期破折強度でみると（図 9), 残 存歯質量が $0 \mathrm{~mm}$ の条件 I は別として, 条件 II〜VIIは
すべて同様の破折強度を示し，すべての築造法のなか で，条件VIIIが有意に最も高い破折強度を示した。すな わち, Sorensen JA ら $(1990)^{30)}$ の所見と同様であっ た。また，破折様相をみると（表 4)，それぞれ特徵 的な様相を示した. 特に, 漏斗状根管であってもレジ ン単体での築造（条件IV）が破折強度, 破折様相いず れにおいても健闘しているのが目を引く．また，残存 


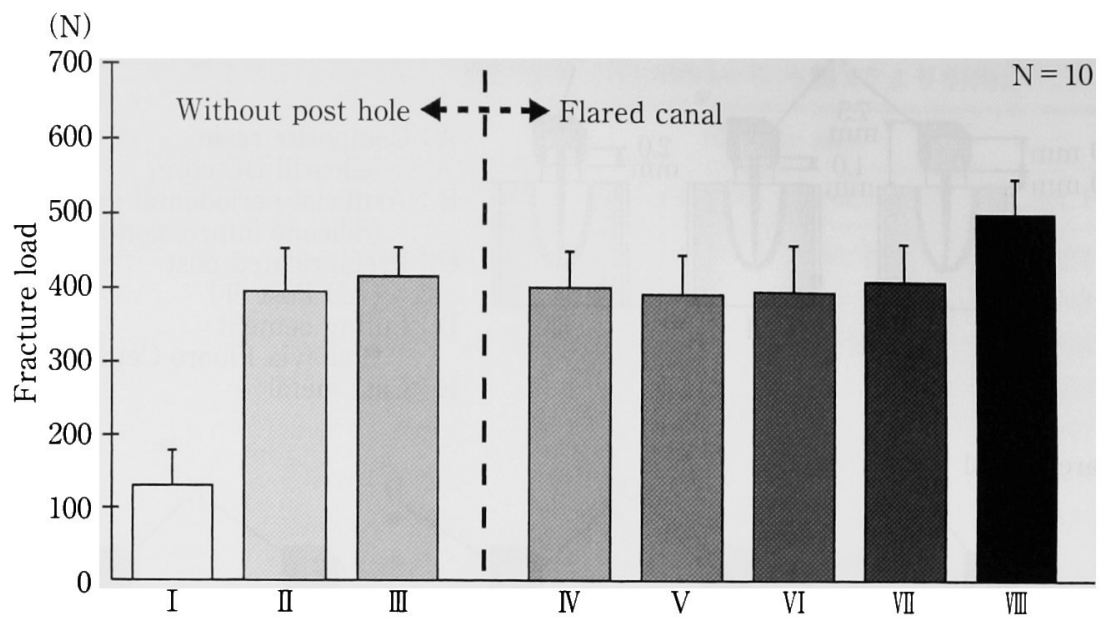

図 9 Initial fracture load for the eight groups (Means and standard deviations) 初期破折強度

表 4 Fracture modes of the specimen types 築造方法別の破折様相

\begin{tabular}{ccccccccc}
\hline \hline & I & II & III & IV & V & VI & VII & VIII \\
\hline A & 8 & 1 & & & & & & \\
B & 2 & 7 & 7 & 8 & 7 & 4 & & \\
C & & 2 & 3 & 2 & 3 & 5 & 4 & \\
D & & & & & & 1 & 6 & 10 \\
\hline
\end{tabular}

歯質量 1 と $2 \mathrm{~mm}$ の条件II, IIIの破折強度に差がみら れず，実験 1 の結果と異なっている。これは，実験 2 では荷重方向を歯軸に対し $45^{\circ}$ 方向（実験 1 では $90^{\circ}$ ）とし，歯根膜を模したシリコーン印象材層を付 与するなど臨床に近い条件となっているためと考えて いる.

実験 2 の結果は, 再利用を考えない最後の手段とし ての鋳造コアの有用性を示している. 同時に, レジン 単体のレジンコアの際立だった可能性を示唆してい る.さらに，既製ポストを併用したレジン築造法の有 用性に疑問を投げかけてもいる。

\section{IV. 設問 3 支台築造に起因するトラブルを 防ぐための要件は何か}

支台築造に起因するトラブルには，根管形成時の穿 孔やポストの破折もあるが，主なトラブルは築造体の クラウンごとの脱落と歯根破折である. 前者を防止す るには築造体が支台歯から脱離しないよう，ポストの
保持力を高める必要がある．また，後者を防止するに は歯根に作用する力を広く分散させ，特定の部位に応 力が集中するのを避けることが有効である．ともに力 を受ける支台歯の問題なので,「受圧要素」と表現す ることができる ${ }^{31}$. さらに, 両者に関連する防止策と して, 当該歯に異常に大きな力が加わるのを防ぐこと がある．すなわち「加圧要素」のコントロールであ る。これらについて項目をあげると下記の通りであ $ろ^{32)}$.

1. 加圧要素をコントロールする

1）ブラキシズムにあらかじめ対処する

2）臼歯部の咬合を確保する

3）無理な設計のブリッジを作らない

4）動きの大きな部分床義歯を作らない

5）硬いものの嗜好を制限する

2. 受圧要素をコントロールする

1）窩洞に亀裂や破折がないか診査する

2）歯冠部歯質をできるかぎり残す

3）ポストの使用はできるかぎり控える

4）ポストを使うときは長いポス卜（歯根長の $2 / 3$ ) を用いる

5）築造窩洞に角ばった部位を作らない

6）ポストは太くしすぎない

7）ポストの接着にはレジンセメントを使う

鋳造コアとレジンコアとの比較において，レジンコ アに既製金属ポストを併用するとき，両者の差は強度 的には非常に少ないものとなる．ファイバーポストは 
この差を多少ともつけることを意図していると理解す ることができる，一方，レジン単体はこれらと明確に 一線を画し，支台築造のあるべき姿を示唆するもので ある。

支台築造は，英語では従来 Post and core と表現さ れることが多かったが，最近はFoundation restoration と記しているのを目にする。これもポストから の脱皮と受け取ることができそうである.

最後にいい古されたことであるが，支台築造のトラ ブルを防止するために最も良い方法は「失活歯にしな いことである」ことを確認したい。

\section{文献}

1）石原正隆. 支台築造された失活歯の残存歯質が破折強度 および破折様相に与える影響. 鶴見歯学 $24: 157-170$, 1998.

2）天川由美子, 石原正隆, 岩並恵一ほか. 支台築造用コン ポジットレジンに関する研究, 第 10 報 各種支台築造 用コンポジットレジンの接着強さについて. 鶴見歯学 21 : 305-311, 1995.

3) Lovdahl PE, Nicholls JI. Pin-retained amalgam core vs. cast-gold dowel-cores. J Prosthet Dent 38 : 507-514, 1977.

4) Trabert KC, Caput AA, Abou-Rass M. Tooth fracture - A comparison of endodontic and restorative treatments. J Endod $4: 341-345,1978$.

5) Guzy GE, Nicholls JI. In vitro comparison of intact endodontically treated teeth with and without endopost reinforcement. J Prosthet Dent 42:36-44, 1979.

6) Trope M, Maltz DO, Tronstad L. Resistance of fracture of restored endodontically treated teeth. Endodont Dent Traumatol 1: 108-111, 1985.

7) Sorensen JA, Martinoff JT. Clinically significant factors in dowel design. J Prosthet Dent $52: 28-35,1984$.

8) Heydecke G, Peters MC. The restoration of endodontically treated, single-rooted teeth with cast or direct posts and cores: A systematic review. J Prosthet Dent $87: 381-386,2002$.

9) Akkayan B, Caniklioglu B. Resistance to fracture of crowned teeth restored with different post systems. Eur J Prosthodont Restor Dent 6 : 13-18, 1998.

10) Assif D, Bitenski A, Pilo R et al. Effect of post design on resistance to fracture of endodontically treated teeth with complete crowns. J Prosthet Dent 69 : 36-40, 1993.

11) Butz F, Lennon A, Heydecke G et al. Survival rate and fracture strength of endodontically treated maxillary incisors with moderate coronal defects restored with different post-and-core system : An in vitro study. Int J Prosthodont 14:58-64, 2001.

12) Kern M, Pleimes AW, Strub JR. Fracture strengths of metallic and all-ceramic post-and-core restorations. Dtsch Zahnärztl Z 50 : 451-453, 1995.

13) Martinez-Insua A, da Silva L, Rilo B et al. Comparison of the fracture resistance of pulpless teeth restored with a cast post and core or carbon-fiber post with a composite core. J Prosthet Dent $80: 527-532,1998$.

14) Perez Moll JF, Howe DF, Svare CW. Cast gold post and core and pin-retained composite resin bases: A comparative study in strength. J Prosthet Dent 40 : 642-644, 1978.

15) Sidoli GE, King PA, Setchell DJ. An in vitro evaluatioin of a carbon fiber-based post and core system. J Prosthet Dent 78:5-9, 1997.

16) Robbins JW, Earnest LA, Schumann SD. Fracture resistance of endodontically-treated cuspids. Am J Dent $6: 159-161,1993$.

17) Isidor F, Brondum K. Intermittent loading of teeth with tapered, individually cast or prefabricated, parallel-sided posts. Int J Prosthodont 5:257-261, 1992.

18) Isidor $\mathrm{F}$, Odman $\mathrm{P}$, Brondum $\mathrm{K}$. Intermittent loading of teeth restored using prefabricated carbon fiber posts. Int J Prosthodont 9: 131-136, 1996.

19) Bergman $B$, Lundquist $P$, Sjogren $U$ et al. Restorative and endodontic results after treatment with cast posts and cores. J Prosthet Dent $61: 10-15,1989$.

20) Hatzikyriakos AH, Reisis GI, Tsingos N. A 3-year postoperative clinical evaluation of posts and cores beneath existing crowns. J Prosthet Dent 67 : 454-458, 1992.

21) Linde LA. The use of composites as core material in root-filled teeth. II. Clinical investigation. Swed Dent J $6: 209-216,1984$.

22) Mentink AG, Creugers NH, Meeuwissen $\mathrm{R}$ et al. Clinical performance of different post and core systems-results of a pilot study. J Oral Rehabil 20 : 577-584, 1993.

23) Mentink AG, Meeuwissen R, Kayser AF et al. Survival rate and failure characteristics of the all metal post and core restoration. J Oral Rehabil $20: 455-461$, 1993.

24) Torbjörner A, Karlsson S, Odman PA. Survival rate and failure characteristics for two post designs. J Prosthet Dent 73 : 439-444, 1995.

25) Stegaroiu R, Yamada H, Kusakari $\mathrm{H}$ et al. Retention and failure mode after cyclic loading in two post and core systems. J Prosthet Dent 75 : 506-511, 1996. 
26）天川由美子. 鋳造支台築造とレジン支台築造の保持力に 関する研究. 補綴誌 42 : 1054-1065, 1998.

27）渡辺厚生. 支台築造に関する研究, 歯冠部残存歯質量の 影響について。補経誌 $34: 7-17,1990$.

28）佐藤範幸，小林國彦，疋田一洋ほか，接着性レジンセメ ントを用いた三種類の支台築造法の辺縁漏洩. 補緅誌 40：1164-1170, 1996.

29）橋本 興, 坪田有史. 漏斗状ポスト孔の支台築造に関す る研究. 補緅誌 46:54-63, 2002.

30) Sorensen JA, Engelman MJ. Effect of post adaptation on fracture resistance of endodontically treated teeth. J Prosthet Dent 64:419-424, 1990.
31）飯島国好. 歯根破折 4-12, 東京: 医歯薬出版, 1994.

32）福島俊士, 坪田有史, 石原正隆. 歯根破折の予防. 東京 歯医師会誌 $47 ： 651-658,1999$.

\author{
著者連絡先：福島 俊士 \\ 于230-8501 神奈川県横浜市鶴見区鶴見 \\ 2-1-3 \\ TEL : 045-581-1001（内線 8411） \\ FAX : 045-573-6898 \\ E-mail : fukushima-s@tsurumi-u.ac.jp
}




\title{
Clinical Consideration of Foundation Restoration for Endodontically Treated Teeth
}

\author{
Fukushima Shunji \\ The Second Department of Prosthetic Dentistry, Tsurumi University School of Dental Medicine
}

J Jpn Prosthodont Soc $47: 261-271,2003$

\section{ABSTRACT}

In daily practice, both cast cores and composite resin cores are used as core materials, though the latter may be with or without a prefabricated metal post. The composite resin core material has been improved and now has the ability to adhere not only to enamel but also to dentin. In addition, the metal post does not reinforce a tooth and therefore can be used only when it is essential for retaining a core. In this sense, it is not important whether the metal is cast or prefabricated. Question 1 (Q 1) from the editor is whether there are special cases for cast cores or composite resin cores and Question $2(\mathrm{Q} 2)$ is, if yes, to cite some instances for both cores. My answer to Q 1 is yes, in cases where metal posts are not necessary, because such cases can be restored with composite resin only. On the other hand, if the cases necessitate posts, it is difficult to distinguish one from the other, at least in mechanical terms. However, such distinction is possible in clinical terms, because there are several merits of prefabricated metal post and composite resin cores, including reduction of time and cost. These are my answers to Q 2. Question 3 ask me to express my opinion regarding clinical ways for preventing troubles such as dislodgement of post and cores and root fracture. Therefore, I propose several guidelines for classifying tooth factors and other factors.

\section{Key words}

cast core, composite resin core, prefabricated post, post and core 